In My Power 


\section{Ibave it}

EARLY AMERICAN STUDIES

Series Editors:

Daniel K. Richter,

Kathleeen Brown, and

David Waldstreicher

Exploring neglected aspects

of our colonial, revolutionary,

and early national history

and culture, Early American

Studies reinterprets familiar

themes and events in fresh

ways. Interdisciplinary in

character, and with a special

emphasis on the period from

about 1600 to 1850 , the series

is published in partnership

with the McNeil Center for

Early American Studies.

A complete list of books

in the series is available

from the publisher. 


\section{In My Power}

Letter Writing

and Communications

in Early America

KONSTANTIN DIERKS

\section{PENN}

University of Pennsylvania Press / Philadelphia 
Copyright (C) 2009 University of Pennsylvania Press

All rights reserved. Except for brief quotations used for purposes of review or scholarly citation, none of this book may be reproduced in any form by any means without written permission from the publisher.

Published by

University of Pennsylvania Press

Philadelphia, Pennsylvania 19104-4112

Printed in the United States of America on acid-free paper

$\begin{array}{llllllllll}10 & 9 & 8 & 7 & 6 & 5 & 4 & 3 & 2 & 1\end{array}$

Library of Congress Cataloging-in-Publication Data

Dierks, Konstantin.

In my power : letter writing and communications in early America / Konstantin Dierks. p. cm.- (Early American studies)

Includes bibliographical references and index.

ISBN 978-0-8122-4153-2 (acid-free paper)

1. American letters-18th century-History and criticism. 2. Letter writing-United States-History-18th century. 3. American letters-History and criticism. I. Title. PS416.D54 2009

$816^{\prime} .309-\mathrm{dc} 22$

2008041883

The epigraphs to this volume come from the following sources: C. Wright Mills, The Sociological Imagination (New York: Oxford University Press, 1959), 3-4; Jacobo Timerman, Prisoner Without a Name, Cell Without a Number (New York: Knopf, 1981), 111; Changez, in Mohsin Hamid, The Reluctant Fundamentalist (Orlando: Harcourt, 2007), 97. 


\section{To Sarah Knott}


